\title{
Cyrioctea (Araneae, Zodariidae) in Africa: temperate Gondwanaland relict, recent radiation, or both?
}

\author{
Rudy C.A.M. JOCQUÉ \\ Royal Museum for Central Africa, Leuvensesteenweg 13, 3080 Tervuren, Belgium. \\ E-mail: rudy.jocque@africamuseum.be \\ urn:Isid:zoobank.org:author:CF15016C-8CD1-4C9D-9021-44CA7DC7A5D5
}

\begin{abstract}
Two new species of the zodariid genus Cyrioctea Simon, 1889 are described: C. sawadee sp. nov. and C. lotzi sp. nov., both only known from males. The genus now contains seven Afrotropical species and this abundance is discussed in the context of its basal situation in the family and its apparent temperate Gondwanaland distribution, which implies a much greater age of the Zodariidae than presently accepted. Unlike most taxa with a temperate Gondwana distribution, Cyrioctea boasts a high number of species with small distribution areas. This points in the direction of a recent radiation initiated after a long period of stasis.
\end{abstract}

Keywords. Cyriocteinae, distribution area, complexity, identification key.

Jocqué R.C.A.M. 2013. Cyrioctea (Araneae, Zodariidae) in Africa: temperate Gondwanaland relict, recent radiation, or both? European Journal of Taxonomy 47: 1-12. http://dx.doi.org/10.5852/ejt.2013.47

\section{Introduction}

The spider genus Cyrioctea is remarkable in many ways. The spiders are characterized by a transverse row of, most often six, short but sturdy spines between the eye rows. These are assumed to constitute a burrowing device. Cyrioctea do indeed live under ground and females, that hardly ever emerge from their burrows, are very rarely collected. Although the position of the genus has been the subject of some debate, these spiders clearly belong to the Zodariidae (Jocqué 1991): they lack a serrula and are provided with long anterior lateral spinnerets. Since the claw teeth are positioned in the axis of the claw, they were considered as the sister group of all other Zodariidae, in which the claws are positioned on the side of the claw facing the other one. The first cladistic analysis of the family on genus level therefore used Cyrioctea as the outgroup. A recent unpublished cladistic analysis (Jocqué 2006) on morphological grounds with Amaurobius as outgroup (see Jocqué \& Dippenaar 2007), finds Cyrioctea in the same position at the root of the Zodariidae, thus sister to all other genera in the family.

Because of its ancestral character it is not surprising to find the genus on three continents: Africa, South America and Australia (Platnick 1986; Platnick \& Griffin 1988; Platnick \& Jocqué 1992). This is a typical temperate Gondwanaland distribution with all the localities on the southern tip of the continents. On the other hand, the complexity of the male genitalia is startling. Moreover, the species appear to have 
very small distribution areas, which is also puzzling as the Gondwanaland relicts have been assumed to be leftovers of old radiations with a large distribution.

The present paper describes two new species, gives an overview and a distribution map of African Cyrioctea species. A key to the males is provided.

\section{Material and methods}

All material is preserved in $70 \%$ ethanol. Specimens were observed and measured with a Leica M10 stereo microscope. Photographs were taken with a Leica MZ16 using the LAS automontage software. Drawings were carried out with a camera lucida on a WILD M5.

All measurements are in millimetres.

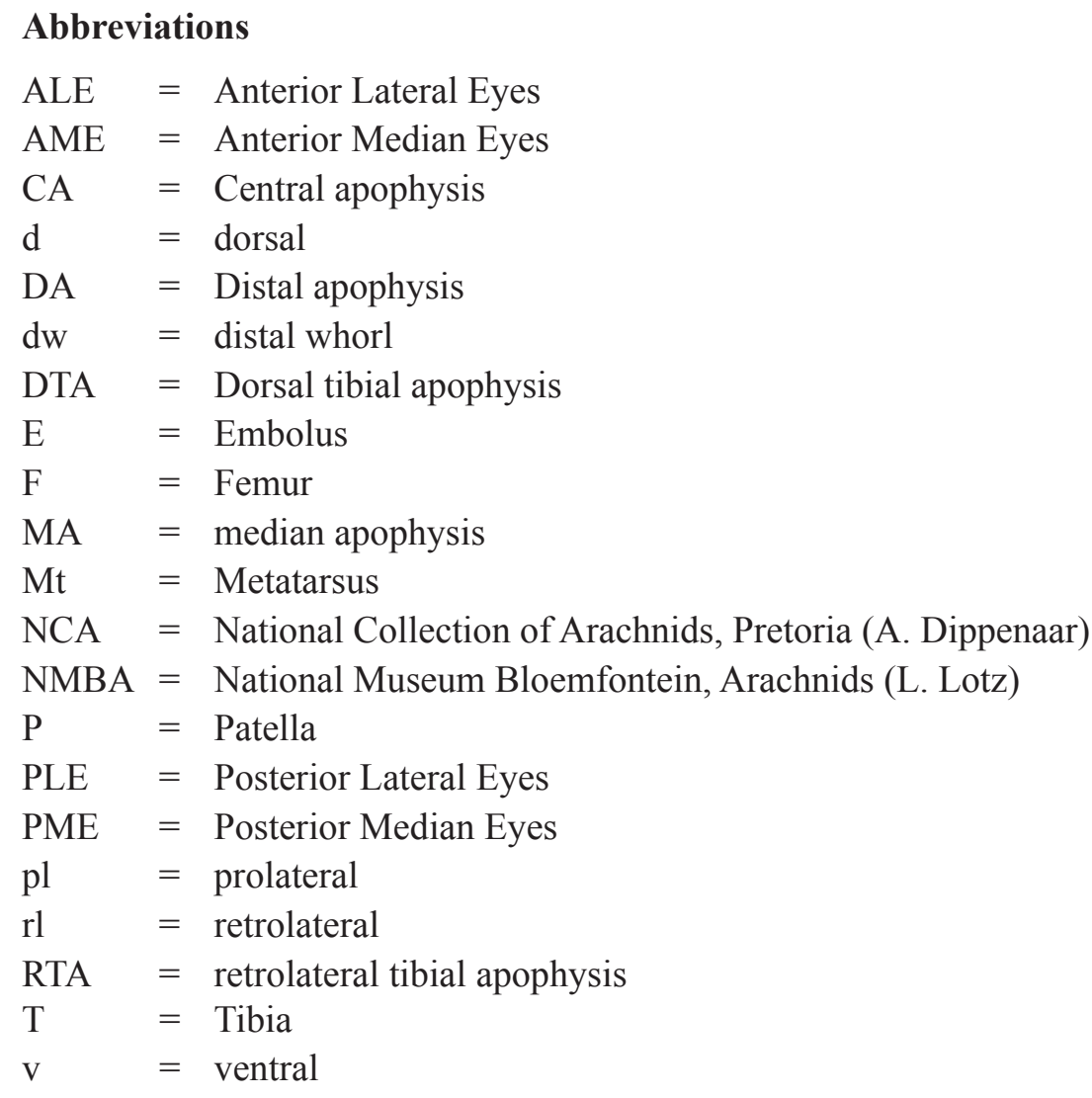

\section{Results}

\section{Taxonomic descriptions}

Class Arachnida Cuvier, 1812

Order Araneae Clerck, 1757

Family Zodariidae Thorell, 1881

Subfamily Cyriocteinae Jocqué, 1991

Genus Cyrioctea Simon, 1889

\section{Remarks}

The genus Cyrioctea was described by Simon (1889), on a species from South America and redescribed in detail by Platnick (1986) and Jocqué (1991). Cyrioctea now contains 13 species of which five occur in 
South America, one in Australia (Platnick 2012) and seven in southern Africa. These African species are C. griswoldorum Platnick \& Jocqué, 1992 (つ̋), C. hirsuta Platnick \& Griffin, 1988 (ㅇ), C. lotzi sp. nov.

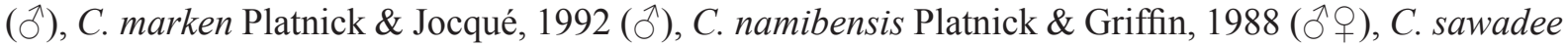
sp. nov. (ふ) and C. whartoni Platnick \& Griffin, 1988 (ぷ+o).

\title{
Key to the males of African Cyrioctea (C. hirsuta only known from females)
}

1 Male palpal tibia with dorsal apophysis clearly separated from broad RTA which is provided with tooth on inferior margin

- Male palpal tibia without dorsal apophysis; RTA without tooth on inferior margin .........................

2 Dorsal apophysis much shorter than RTA, which is roughly triangular and pointed; abdomen dark grey except for white spot above spinnerets C. griswoldorum Platnick \& Jocqué, 1992

- Dorsal apophysis almost as long as RTA, which is roughly rectangular and broadly truncated; abdomen pale with dark pattern of central spot followed by transverse bands (Fig 1A) .......C. sawadee sp. nov.

3 RTA a single sharp, down-curved prong .................................. namibensis Platnick \& Griffin, 1988

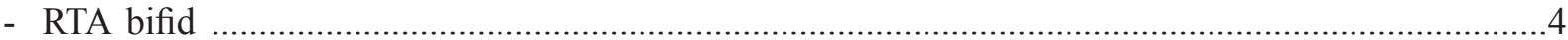

4 Ventral tip of RTA longer than dorsal tip; distal tegular apophysis with narrow tip C. whartoni Platnick \& Griffin, 1988

- Ventral tip of RTA shorter than dorsal tip; distal tegular apophysis broadly truncated .........................5

5 Ventral tip of RTA a tiny prong, much smaller than dorsal tip; median apophysis without median spur at base (Fig. 3E)

C. lotzi sp. nov.

- Ventral tip of RTA not so small; median apophysis with median spur at base

C. marken Platnick \& Jocqué, 1992

\author{
Cyrioctea sawadee sp. nov. \\ urn:1sid:zoobank.org:act:8C7A2AA2-79C5-4EDA-BC0F-29FF40058A66
}

Figs 1A-C, 2A-B, 3A-C, 4

\section{Diagnosis}

The male of $C$. sawadee sp. nov. can be recognized by the modified third leg with dense spination and very short tibia, and by the characters of the palp, of which the tooth on the ventral margin of the RTA is the most conspicuous. That character is shared with $C$. griswoldorum, which has a shorter dorsal tibial apophysis, the shape of the RTA is triangular rather than rectangular and the abdominal pattern consists of one pale spot on a dark background.

\section{Etymology}

The species name is a noun in apposition taken from the type locality.

\section{Type material}

\section{Holotype}

SOUTH AFRICA: ${ }^{\Uparrow}$, Western Cape Province, Sawadee, $32^{\circ} 20.316^{\prime} \mathrm{S}-18^{\circ} 49.405^{\prime}$ E, Oct. 2007, pittrap, 359 m alt., Nortje E. \& Kritzinger-Klopper (NCA).

\section{Paratypes}

$2 \widehat{\partial} \hat{\partial}$, same data as holotype. 


\section{Other material examined}

None.

\section{Description}

Male (holotype, Fig. 1A-C)

MEASUREMENTS. Total length 4.32; carapace 2.14 long, 1.22 wide; TI+PI: 1.95.

Colour. Carapace brownish yellow with black fovea and dark margin; palp, chelicerae, mouthparts and sternum pale brown; legs yellow, femora suffused with dark grey; abdomen pale grey with dark pattern of central spot followed by four transverse bands; venter medium grey, darkened towards yellow spinnerets.

Cephalothorax. Clypeus centre devoid of setae but with dense cluster of inward curved thick setae on either side. Eye region with a row of six slightly curved spines (Figs 1B, 3A), on right side with one short thick extra seta.Chilum poorly developed, inconspicuous. Sternum subcircular, with rather long, thin, posterior extension.

Eyes. AME: 0.04; ALE: 006; AME-AME: 0.08; AME-ALE: 0.01; PME: 0.06: PLE: 0.06; PME-PME: 0.05; PME-PLE: 0.07. Clypeus 0.17 or 2.9 times width of ALE.

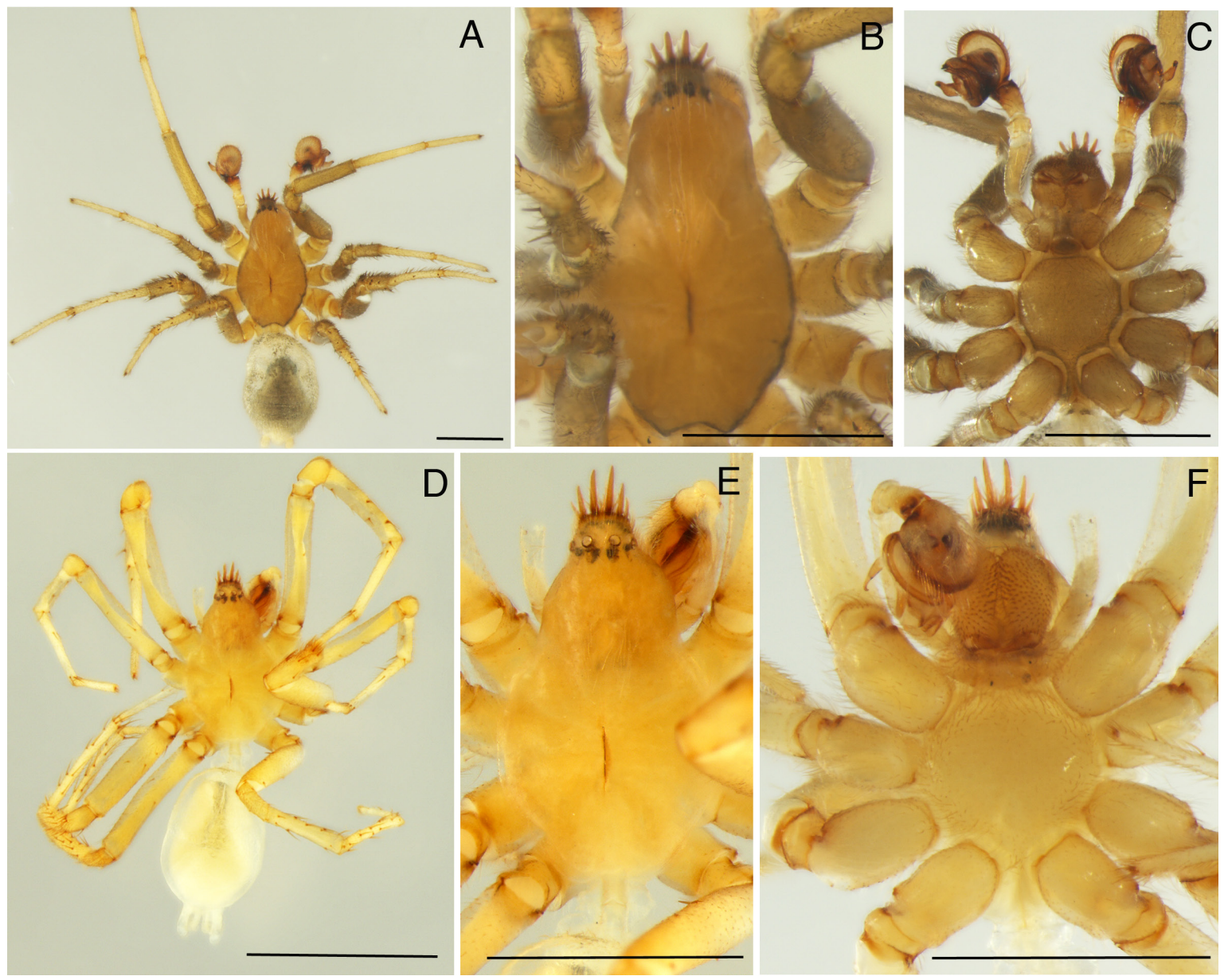

Fig. 1. - A-C. Cyrioctea sawadee sp. nov., ふૈ. A. Habitus, dorsal view. B. Carapace, dorsal view. C. Idem, ventral view. - D-F. Cyrioctea lotzi sp. nov., ô. D. Habitus, dorsal view. E. Carapace, dorsal view. F. Idem, ventral view. (Scale bars: $2 \mathrm{~mm}$ ). 
JOQCUÉ R.C.A.M., Cyrioctea in Africa: relict, recent radiation or both?

LEGs. Legs III modified, provided with numerous spines; femora slightly swollen, spineless, tibiae short, as long as patella.

SPINATION.

\begin{tabular}{|c|c|c|c|c|}
\hline & F & P & T & Mt \\
\hline I & d1 & - & v2 & d1-1v2 \\
\hline II & d1 & - & rl1v2 & v2 \\
\hline III & - & pl3rl1-2 & pl1-1-1d2-15rl1-1v2 & 7dispdw6 \\
\hline IV & d1 & pl2rl1 & pld1-1-1r11-1v2-2-2 & 8dispdw6 \\
\hline
\end{tabular}
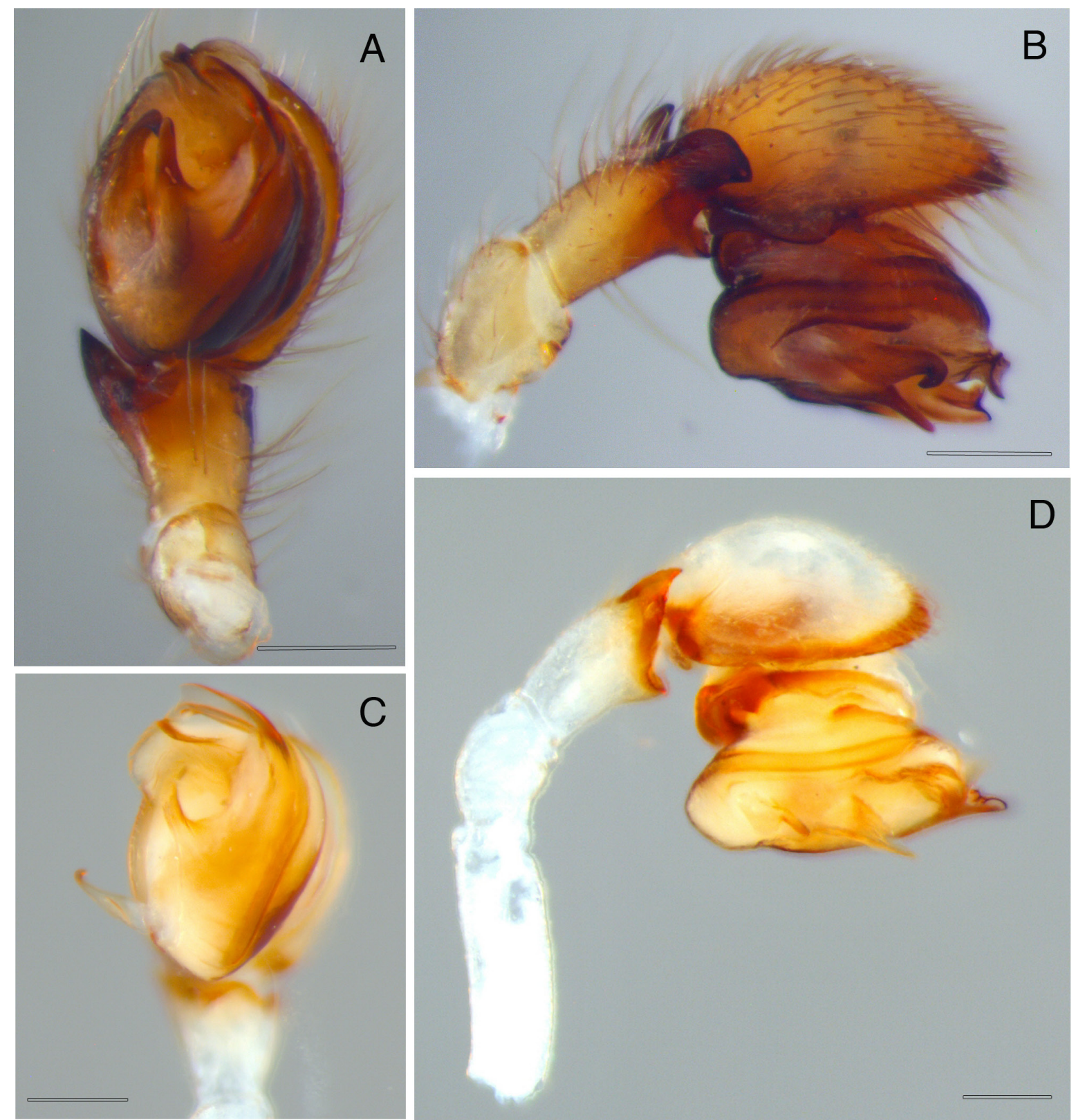

Fig. 2. - A-B. Cyrioctea sawadee sp. nov., ô. A. Palp, ventral view. B. Idem, retrolateral view. - C-D. Cyrioctea lotzi sp. nov., §. C. Palp, ventral view. D. Idem, retrolateral view. (Scale bars: $200 \mu \mathrm{m}$ ). 

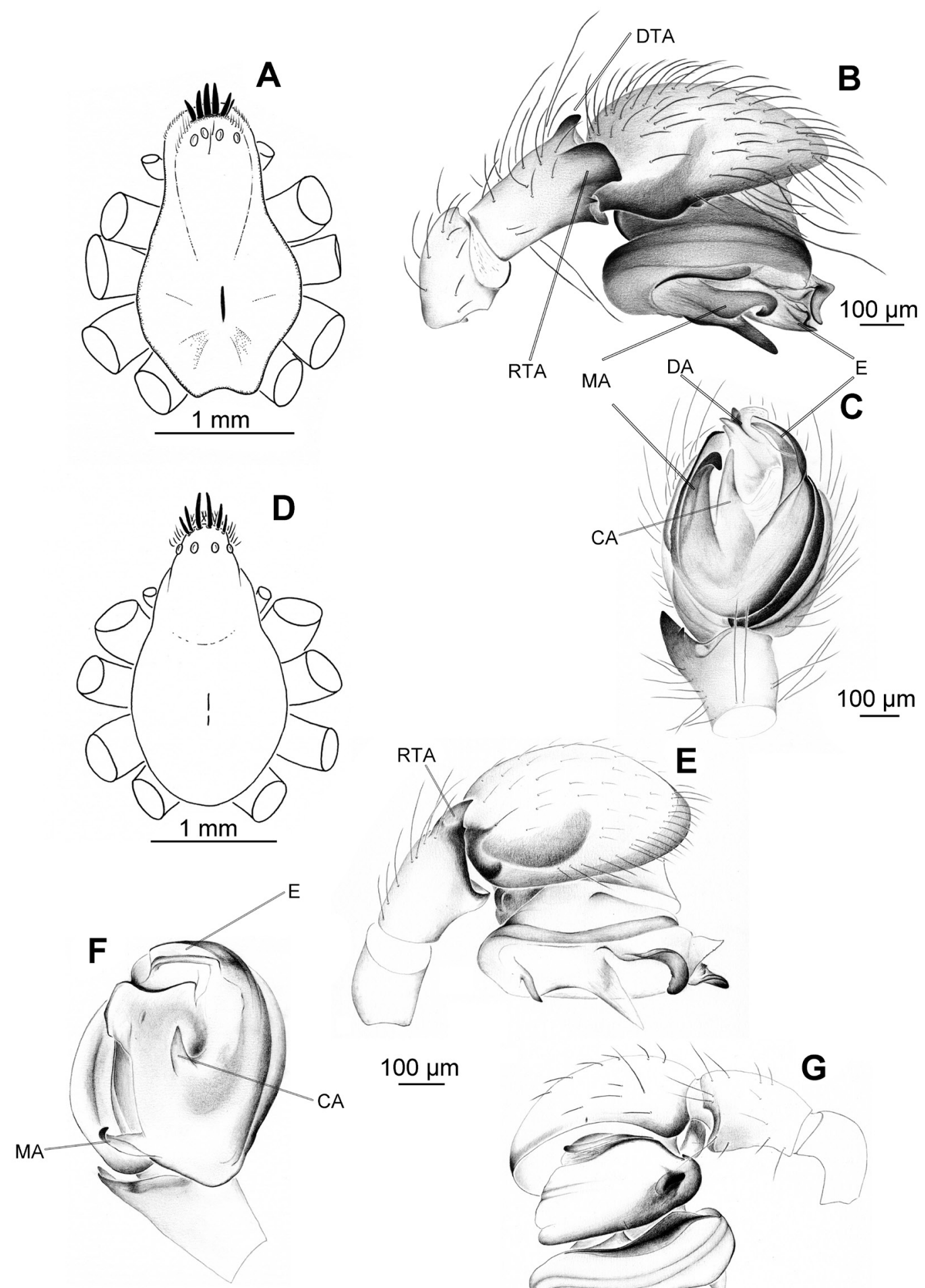

RTA
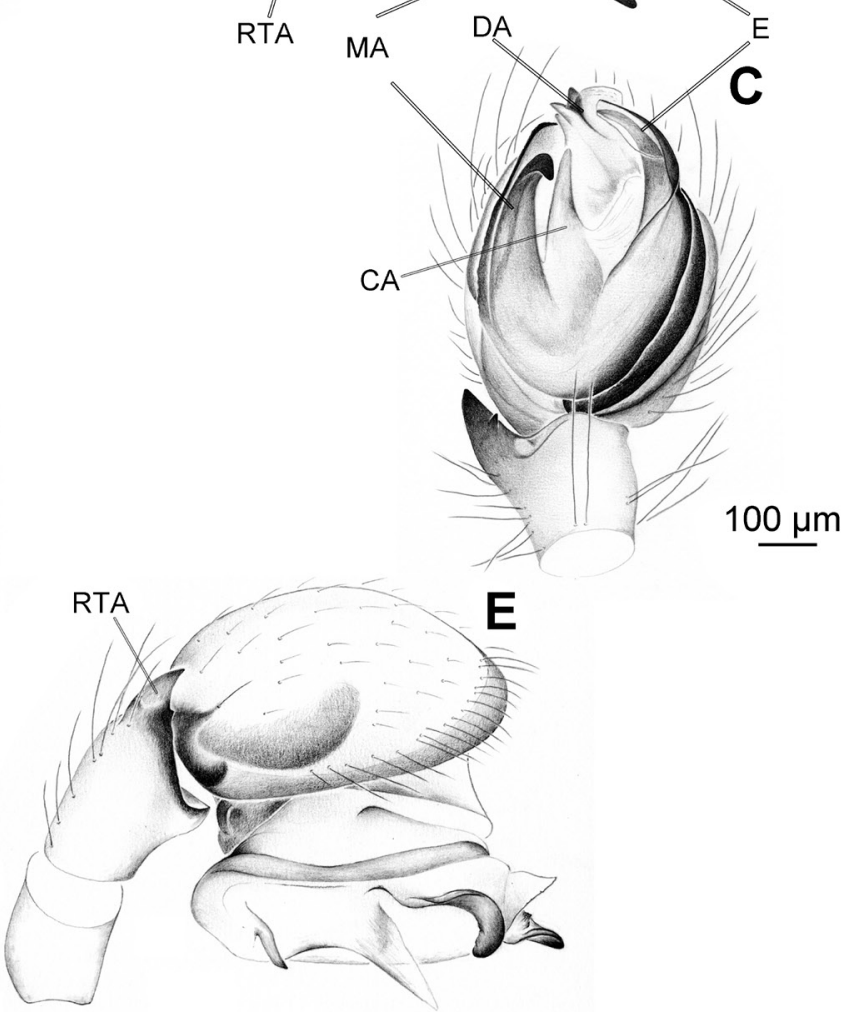

$10 \underline{\mu \mathrm{m}}$

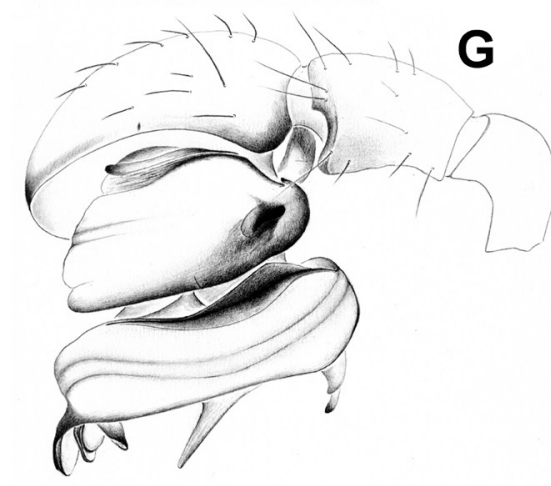

Fig. 3. - A-C. Cyrioctea sawadee sp. nov., ô. A. Carapace, dorsal view. B. Palp, retrolateral view. C. Idem, ventral view. - D-G. Cyrioctea lotzi sp. nov., ふ̂. D. Carapace, dorsal view. E. Palp, retrolateral view. F. Idem, ventral view. G. Idem, prolateral view. CA: central tegular apophysis; DA: distal tegular apophysis; DTA: dorsal tibial apophysis; E: embolus; MA: median apophysis; RTA: retrolateral tibial apophysis. 
Male PalP. (Figs 2A-B, 3 B-C) Tibia with short, triangular dorsal apophysis; RTA broad with dorsal margin smoothly curved down, ventral margin straight, with small tooth at base; cymbium oval, with sclerotized rim, slightly bulging near RTA. Tegulum strongly bulging and complex; embolus prolateral, broad and with semitransparent proximal flange, smoothly curved outwards; median apophysis near retrolateral margin, curved downward, ventrally concave; central apophysis (CA) with digitiform sclerotized tip; distal apophysis (DA) with three short prongs.

\section{Female}

Unknown

\section{Distribution}

Only known from type locality in the Western Cape Province (Fig. 4).

Cyrioctea lotzi sp. nov. urn:1sid:zoobank.org:act:57043731-C00D-4705-913A-5DDFE5681F97

Figs 1D-F, 2C-D, 3D-G, 4

\section{Diagnosis}

The male of $C$. lotzi sp. nov. can be recognized by the pale abdomen with faint dorsal stripe, the strong spines on the first leg and the details of the male palp in which the RTA is adjacent to the dorsal apophysis.

\section{Etymology}

The species name is a patronym in honour of one of the collectors.

\section{Type material}

\section{Holotype}

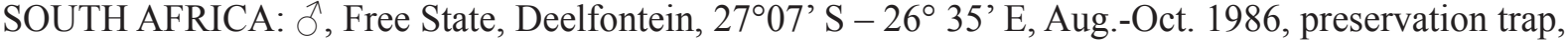
Museum Staff (NMBA).

\section{Paratypes}

$4 \widehat{\partial} \widehat{\partial}$, same data as holotype (1 $\widehat{\partial}$ in MRAC).

\section{Other material examined}

None.

\section{Description}

Male (holotype, Fig. 1D-F)

MEASUREMENTS. Total length 4.54; carapace 2.30 long, 1.31 wide; TI+PI: 2.40 .

Colour. Carapace brownish yellow with black fovea and dark margin; palp, chelicerae, mouthparts, sternum and legs yellow; femora suffused with dark grey; abdomen pale grey with faint darker dorsal median stripe; venter and spinnerets pale.

Cephalothorax. Clypeus provided with dense cluster of short upturned thick setae. Eye region with a row of six slightly curved spines (Figs 1E, 3D). Chilum poorly developed, inconspicuous. Sternum oval; slightly wider than long with rather long, thin, sharp posterior extension.

Eyes. AME: 0.06; ALE: 007; AME-AME: 0.13; AME-ALE: 0.0; PME: 0.09; PLE: 0.08; PME-PME: 0.08 ; PME-PLE: 0.06. Clypeus 0.16 or 2.2 times width of ALE. 
Legs. Legs I with numerous and strong but short spines; legs III with hair cover slightly denser than other legs.

SPINATION.

\begin{tabular}{|c|c|c|c|c|}
\hline & F & P & T & Mt \\
\hline I & d1 & - & pl1-1-2rl1-1v1-1-1-1-1 & v2-2 \\
\hline II & d1 & - & pl1-1rl1-1-1v3 & v2dw3 \\
\hline III & d1 & pl3d1r11 & 6dispv2 & 8dispdw6 \\
\hline IV & d1v1 & rl1 & pld1-1d1-1r11-1-1v2-2-2 & 8dispdw6 \\
\hline
\end{tabular}

Male palp. (Figs 2C-D, 3E-G) Tibia with short, triangular dorsolateral apophysis, adjacent to slightly shorter RTA; cymbium almost rounded, with sclerotized rim, thickened near RTA. Tegulum strongly bulging and complex: embolus distal, provided with transparent flange; median apophysis near posterior retrolateral margin; central apophysis triangular; distal part of tegulum a transverse ridge with sclerotized rim.

\section{Female}

Unknown.

\section{Distribution}

Only known from type locality in the Free State, South Africa (Fig. 4).

\section{Discussion}

Taxa with a temperate Gondwana distribution, also called an Austral distribution (Humphreys \& Parenti 1999), found on the southern tip of the continents Australia, Africa and South America, sometimes including New Zealand and New Caledonia, have been considered to be relicts (e.g. Crisci et al. 1991; Robertson \& Holzenthal 2005). This type of distribution is often synonymous with the presence of ancestral characters, which is also the case for Cyrioctea. Other examples are the ancestral Ratites, flightless birds (Bourdon et al. 2009), Pleurodira, primitive turtles (Sterli 2010) and beetles that are herbivorous on Araucaria (Sequeira \& Farrel 2001). Some of these have been qualified as living fossils as they are at the base of old, large clades. Such groups, albeit rarely exhibiting a Gondwana-distribution, are most often very poor in species, e.g., Tuatara (Hay et al. 2010), Platypus (Groves 2005), Coelacanths (Forey 1998) etc. However, this phenomenon cannot be qualified as a rule since there are remarkable exceptions. The "primitive" spiders with segmented abdomen belonging to the family Liphistiidae are an excellent example of such an exception: the family is composed of 5 genera and contains not less than 85 species (Platnick 2012). And in spider families for which a detailed phylogenetic analysis is available, it is not the rule that basal genera are species poor. It might be so for Lordhowea Griswold, 2001 in Cyatholipidae (Griswold 2001) or Pararchaea Forster, 1955 in Pararchaeidae (Rix 2006), but in Theridiidae, for instance, the most basal genus is the speciose Dipoena Thorell, 1869 (Agnarsson 2004). Also in families like Linyphiidae (Miller \& Hormiga 2004), Ctenidae (Silva 2003) and Thomisidae (Benjamin et al. 2008), the most basal genera are rich in species. Thus it is certainly not a general phenomenon that basal taxa of a large evolutionary line tend to be relicts in the sense that they are poor in species.

But also from the morphological point of view, certain characters and more precisely the genitalia of Cyrioctea, are puzzling. In the Zodariidae, the root of the large clades is very often occupied by species with very simple genitalia. A recurring pattern is the presence of a short, straight, spine-like embolus accompanied by a short and simple median apophysis and a simple RTA in the species near 
the root, evolving to a long embolus accompanied by intricate supporting structures and the addition of apophyses on the palpal patella and even the femur. Examples are Diores namibia Jocqué, 1991 for Diores with more than 50 species (Jocqué 1991), Tenedos infrarmatus Jocqué \& Baert, 2002 at the base of a large clade containing the genera Tenedos, Ishania, Epicratinus and Colima (Jocqué \& Baert 2005), Procydrela procursor Jocqué, 1999 at the base of the Cydrelinae (Jocqué 1999), and Pentasteron simplex Baehr \& Jocqué, 2001 at the base of the very large Asteron complex in which more than 100 species have already been described (Baehr \& Jocqué 2001).

In other families where a similar phenomenon is assumed to occur, the trend is often obscured by the creation of separate genera exactly on the basis of these additional structures on palpal patella and femur (e.g. Wang 2002). Data on the Zodariidae, one of the few families for which there is a combination of generic and species phylogenies, show that a somatic radiation precedes the genital one. But Cyrioctea, does not qualify. All the species have a complex bulbus with several tegular appendages. In several species, however, the palpal tibia shows a typical ancestral character with the presence of a dorsal apophysis, which may be the precursor of the retrolateral tibial apophysis (RTA). But the complexity of the bulbus is incoherent with the idea that Cyrioctea might be considered a living fossil dating back from the split-off of Gondwanaland. It might therefore be argued that a recent radiation has occurred, explaining the existence of closely related species with small distribution areas. Such a recent radiation

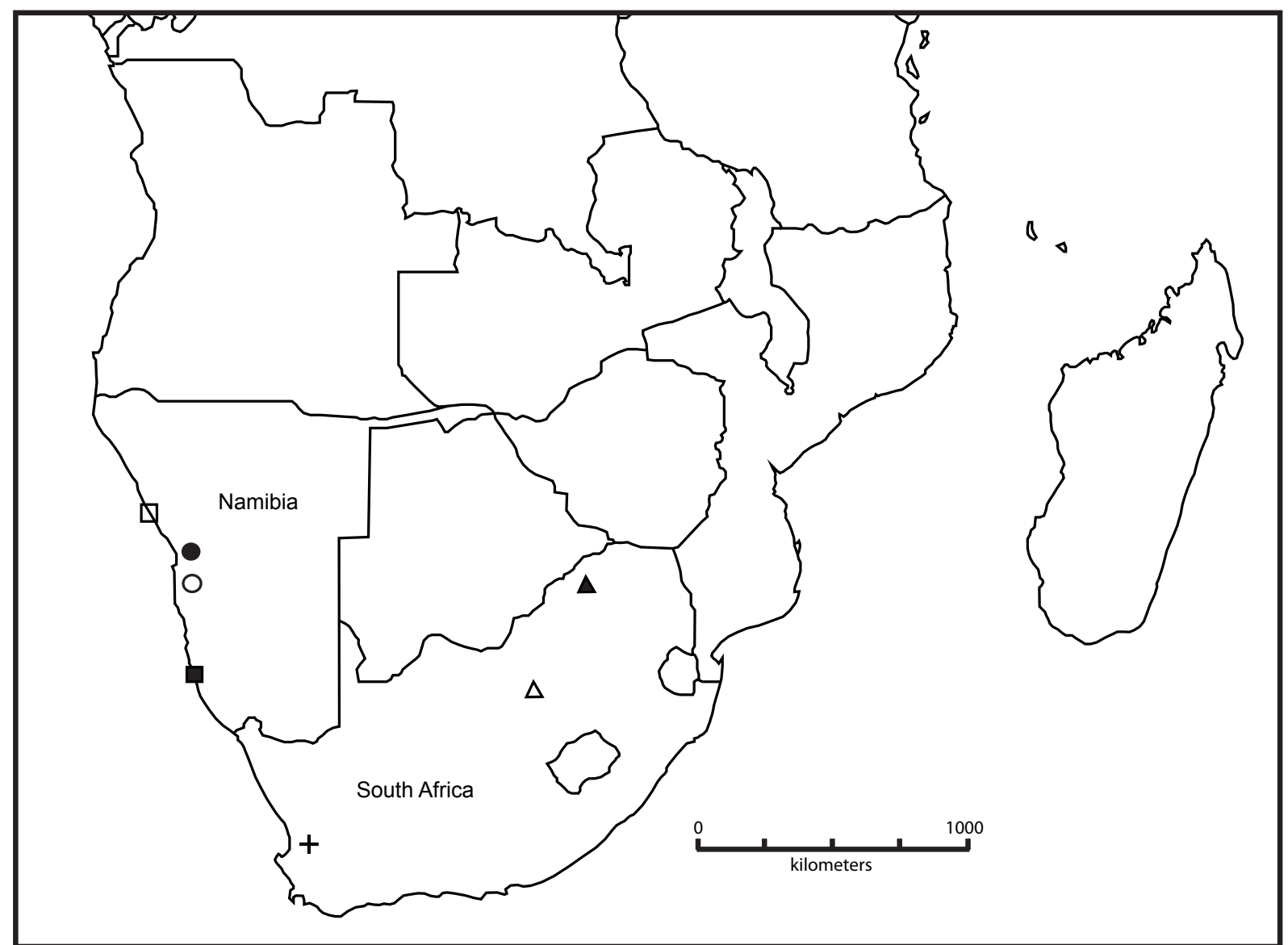

Fig. 4. Distribution of Cyrioctea species in Africa: $(\square)=$ C. griswoldorum Platnick \& Jocqué, 1992; ( $\square)$ $=$ C. hirsuta Platnick \& Griffin, 1988; $(\Delta)=$ C. lotzi sp. nov.; $(\mathbf{\Delta})=$ C. marken Platnick \& Jocqué, 1992; $(\bullet)=$ C. namibensis Platnick \& Griffin, 1988; $(+)=$ C. sawadee sp. nov.; $(\circ)=$ C. whartoni Platnick \& Griffin, 1988. 
is known for the plants belonging to the Cycadales, considered a group of "living fossils" until recently (Nagalingum et al. 2011). Neither the Liphistiidae nor Cyrioctea have been subject to such a detailed analysis, but may well represent other examples of old taxa with a recent radiation. However, the most important consequence of Cyrioctea's distribution is that the family is much older than what is proposed in Penney \& Selden (2011). Following Miller et al. (2010a, 2010b), they consider Zodariidae the sister family of Penestomidae and conclude that the clade is not older than $30 \mathrm{ma}$. Since it must date back from before the split up of western Gondwanaland, its age must be pushed back to at least 100 ma (Pitman et al. 1993).

It is evident that only a detailed cladistic analysis including molecular data can corroborate the hypothesis that has been formulated here.

\section{Acknowledgements}

I am indebted to A. Dippenaar-Schoeman (NCA, Pretoria) and L. Lotz (NMBA, Bloemfontein) for the loan of material. I have appreciated the discussions with Marc De Meyer and Jos Snoeks concerning temperate Gondwana distributions. I thank Alain Reygel for the drawings.

\section{References}

Agnarsson I. 2004. Morphological phylogeny of cobweb spiders and their relatives (Araneae, Araneoidea, Theridiidae). Zoological Journal of the Linnean Society 141: 447-626. http://dx.doi.org/10.1111/j.10963642.2004.00120.x

Baehr B. \& Jocqué R. 2001. Revisions of genera in the Asteron-complex (Araneae: Zodariidae): new genera Pentasteron, Phenasteron, Leptasteron and Subasteron. Memoirs of the Queensland Museum 46: 359-385.

Benjamin S.P., Dimitrov D., Gillespie R.G. \& Hormiga G. 2008. Family ties: molecular phylogeny of crab spiders (Araneae: Thomisidae). Cladistics 24: 708-722. http://dx.doi.org/10.1111/j.10960031.2008.00202.x

Bourdon E., De Ricqlès A. \& Cubo J. 2009. A new Transantarctic relationship: morphological evidence for a Rheidae-Dromaiidae-Casuariidae clade (Aves, Palaeognathae, Ratitae). Zoological Journal of the Linnean Society 156: 641-663. http://dx.doi.org/10.1111/j.1096-3642.2008.00509.x

Crisci J.V., Cigliano M.M., Morrone J.J. \& Riog-Juñent S. 1991. Historical biogeography of southern South America. Systematic Zoology 40: 152-171. http://dx.doi.org/10.1093/sysbio/40.2.152

Forey P.L. 1998. History of the Coelacanth Fishes. Chapman \& Hall, London.

Griswold C.E. 2001. A monograph of the living world genera and Afrotropical species of cyatholipid spiders (Araneae, Orbiculariae, Araneoidea, Cyatholipidae). Memoirs of the California Academy of Sciences 26: 1-251.

Groves C.P. 2005. Order Monotremata. In: Wilson D.E. \& Reeder D.A. (eds) Mammal Species of the World: a Taxonomic and Geographic Reference. Volumes 1-2. John Hopkins University Press, Baltimore.

Hay J.M., Sarre S.D., Lambert D.M., Allendorf F.W. \& Daugherty C.H. 2010. Genetic diversity and taxonomy: a reassessment of species designation in Tuatara (Sphenodon: Reptilia). Conservation Genetics 11: 1063-1081. http://dx.doi.org/10.1007/s10592-009-9952-7

Humphries C.J. \& Parenti L.R. 1999. Cladistic Biogeography. Interpreting patterns of plant and animal distribution. Oxford University Press, Oxford. 
Jocqué R. 1991. A generic revision of the spider family Zodariidae (Araneae). Bulletin of the American Museum of Natural History 201: 1-160.

Jocqué R. 1999. The new genera Procydrela and Rotundrela, sister taxa for Storenomorphinae and Cydrelinae (Araneae: Zodariidae). Entomologica Scandinavica 30: 225-240. http://dx.doi. org/10.1163/187631200X00264

Jocqué R. 2006. Keeping up the morphology approach: phylogeny of the Zodariidae (Araneae) revisited. European Colloquium of Arachnology, Sitges, Barcelona. Abstracts: 56.

Miller J.A., Griswold C.E. \& Haddad C.R. 2010a. Taxonomic revision of the spider family Penestomidae (Araneae, Entelegynae). Zootaxa 2534: 1-36.

Miller J.A., Carmichael A., Ramírez M.J., Spagna J.C., Haddad C.R., Rezác M., Johannesen J., Král J., Wang X.P. \& Griswold C.E. 2010b. Phylogeny of entelegyne spiders: affinities of the family Penestomidae (NEW RANK), generic phylogeny of Eresidae, and asymmetric rates of change in spinning organ evolution (Araneae, Araneoidea, Entelegynae). Molecular Phylogeny and Evolution 55: 786-804. http://dx.doi.org/10.1016/j.ympev.2010.02.021

Miller J.A. \& Hormiga G. 2004. Clade stability and the addition of data: A case study from erigonine spiders (Araneae: Linyphiidae, Erigoninae). Cladistics 20: 385-442. http://dx.doi.org/ 10.1111/j.1096$\underline{0031.2004 .00033 . \mathrm{x}}$

Nagalingum N.S., Marshall C.R., Quental T.B., Rai H.S., Little D.P. \& Mathews S. 2011. Recent synchronous radiation of a living fossil. Science 334: 796-799. http://dx.doi.org/10.1126/science.1209926

Penney D. \& Selden P.A. 2011. Fossil Spiders: the evolutionary history of a mega-diverse order. Monograph Series, Volume 1. Siri Scientific Press, Manchester.

Pitman III W.C., Cande S., LaBrecque J. \& Pindell J. 1993. Fragmentation of Gondwana: The separation of Africa from South America. In: P. Goldblatt (ed.) Biological Relationships between Africa and South America: 15-31. Yale University Press, New Haven.

Platnick N.I. 1986. A review of the spider genus Cyrioctea (Araneae, Zodariidae). American Museum Novitates 2858: 1-9.

Platnick N.I. 2012. The world spider catalog. Version 12.5. American Museum of Natural History, online at http://research.amnh.org/iz/spiders/catalog. [accessed 12 Apr. 2012]

Platnick N.I. \& Griffin E. 1988. On the first African and Australian spiders of the genus Cyrioctea (Araneae: Zodariidae). Journal of the New York Entomological Society 96: 359-362.

Platnick N.I. \& Jocqué R. 1992. Two new species of Cyrioctea from southern Africa with a note on sexual dimorphism in the genus (Araneae, Zodariidae). Journal of African Zoology 106: 191-196.

Rix M.G. 2006. Systematics of the Australasian spider family Pararchaeidae (Arachnida: Araneae). Invertebrate Systematics 20: 203-254.

Robertson D.R. \& Holzenthal R.W. 2005. The Neotropical caddisfly genus Tolhuaca (Trichoptera: Glossosomatidae). Zootaxa 1063: 53-68.

Sequeira A.S. \& Farrell B.D. 2001. Evolutionary origins of Gondwanan interactions: How old are Araucaria beetle herbivores? Biological Journal of the Linnean Society 74: 459-474. http://dx.doi. org/10.1111/j.1095-8312.2001.tb01405.x

Silva D.D. 2003. Higher-level relationships of the spider family Ctenidae (Araneae: Ctenoidea). Bulletin of the American Museum of Natural History 274: 1-86. 
Simon E. 1889. Etudes arachnologiques. 21e Mémoire. XXX. Descriptions de quelques arachnides du Chili et remarques synonymiques sur quelques unes des espèces décrites par Nicolet. Annales de la Société entomologique de France 8: 217-222.

Sterli J. 2010. Phylogenetic relationships among extinct and extant turtles: the position of Pleurodira and the effects of the fossils on rooting crown-group turtles. Contributions to Zoology 79 (3): 93-106.

Wang X.P. 2002. A generic-level revision of the spider subfamily Coelotinae (Araneae, Amaurobiidae). Bulletin of the American Museum of Natural History 269: 1-150.

Manuscript received: 30 January 2013

Manuscript accepted: 16 April 2013

Published on: 13 June 2013

Topic editor: Koen Martens

Desk editor: Kristiaan Hoedemakers

Printed versions of all papers are also deposited in the libraries of the institutes that are members of the EJT consortium: Muséum National d'Histoire Naturelle, Paris, France; National Botanic Garden of Belgium, Meise, Belgium; Royal Museum for Central Africa, Tervuren, Belgium; Natural History Museum, London, United Kingdom; Royal Belgian Institute of Natural Sciences, Brussels, Belgium; Natural History Museum of Denmark, Copenhagen, Denmark. 